\title{
บusisersaly
}

\section{Sport and terrorism: Two of modern life's most prevalent themes}

Hassan, D. (2012). Sport and terrorism: Two of modern life's most prevalent themes. International Review for the Sociology of Sport, 47(3), 263-267. https://doi.org/10.1177/1012690211433450

Link to publication record in Ulster University Research Portal

\section{Published in:}

International Review for the Sociology of Sport

Publication Status:

Published (in print/issue): 01/06/2012

DOI:

$10.1177 / 1012690211433450$

\section{Document Version}

Publisher's PDF, also known as Version of record

\section{General rights}

Copyright for the publications made accessible via Ulster University's Research Portal is retained by the author(s) and / or other copyright owners and it is a condition of accessing these publications that users recognise and abide by the legal requirements associated with these rights.

\section{Take down policy}

The Research Portal is Ulster University's institutional repository that provides access to Ulster's research outputs. Every effort has been made to ensure that content in the Research Portal does not infringe any person's rights, or applicable UK laws. If you discover content in the Research Portal that you believe breaches copyright or violates any law, please contact pure-support@ulster.ac.uk. 


\title{
International Review for the Sociology of Sport \\ http://irs.sagepub.com/
}

Sport and terrorism: Two of modern life's most prevalent themes David Hassan

International Review for the Sociology of Sport 2012 47: 263

DOI: $10.1177 / 1012690211433450$

The online version of this article can be found at:

http://irs.sagepub.com/content/47/3/263

\author{
Published by: \\ (S)SAE \\ http://www.sagepublications.com \\ On behalf of: \\ International Sociology of Sport Association
}

Additional services and information for International Review for the Sociology of Sport can be found at:

Email Alerts: http://irs.sagepub.com/cgi/alerts

Subscriptions: http://irs.sagepub.com/subscriptions

Reprints: http://www.sagepub.com/journalsReprints.nav

Permissions: http://www.sagepub.com/journalsPermissions.nav

Citations: http://irs.sagepub.com/content/47/3/263.refs.html

>> Version of Record - May 30, 2012

What is This? 


\section{Sport and terrorism: Two of modern life's most prevalent themes}

International Review for the Sociology of Sport 47(3) 263-267

(C) The Author(s) 2012 Reprints and permission: sagepub.co.uk/journalsPermissions.nav DOI: $|0.1| 77 /|0| 26902|| 433450$ irs.sagepub.com

@SAGE

\title{
David Hassan
}

University of Ulster, Northern Ireland, UK

\begin{abstract}
The purpose of this introduction is to establish the context for the ensuing collection examining the relationship between sport and terrorism within a range of international sporting settings. Drawing upon a host of recent examples this article serves to demonstrate the multifaceted nature of this relationship, how it emerges in remarkably similar fashions within otherwise quite diverse locations and how sport is increasingly being targeted by terrorists irrespective of whether their campaigns are considered to be 'local' or global in nature. It argues that terrorists exercise impact both through the direct targeting of sport and also, subsequently, the diffusion out from these real or intentional events to impact upon many aspects of political and civic life.
\end{abstract}

\section{Keywords}

international events, sport, terrorism

Despite very public examples of the interplay between sport and terrorism throughout the history of modern sport there was still something quite shocking about the attack upon the Sri Lankan cricket team bus, en route to a Test match against Pakistan in Lahore, on 3 March 2009. A total of eight people lost their lives and a further six were injured as a result of the attack, thought to have been the work of Islamic militants, which took place less than six months after a series of co-ordinated terrorist attacks in Mumbai, India. Indeed, in a tragic twist of fate, Sri Lanka only agreed to play Pakistan in the game in question following the withdrawal of India from the original fixture, the latter evermore mindful of the possibility of escalating violence and terrorist attacks following the incidents of November 2008 in their home country (Berry, 2009).

Thus even the fear of attack in Pakistan has exercised an affect on touring nations, such as India. Australia has refused to play a Test match in the country since 1998, whilst

\section{Corresponding author:}

David Hassan, Room I5E0IE, Ulster Sports Academy, University of Ulster at Jordanstown, Shore Road, Newtownabbey, County Antrim BT37 0QB, Northern Ireland, UK.

Email: d.hassan@ulster.ac.uk 
its neighbour New Zealand was extremely fortunate to avoid casualties when, during a cricket tour to the country in 2002, a suicide bomb blast outside the team's hotel in the southern Pakistani city of Karachi narrowly avoided injuring the players but did claim the lives of 11 French Navy experts and 14 people in total. However, what perhaps made the more recent events in Lahore particularly noteworthy were their inherent ruthlessness, the very public nature of the attack and the stark manner in which the vulnerability of sport to acts of terrorism was exposed (Wilkinson, 2001). Amid the global significance of sport, embedded as it is into the very fabric of most nations throughout the world, it is increasingly apparent that terrorist cells intent on promoting their message on the world stage consider sport to be a very effective means of achieving this strategic aim (Taylor and Toohey, 2007).

Still more recent was the gun attack upon the Toga national team bus carrying the squad to a training session prior to the Africa Cup of Nations staged in Angola during January 2010. An organization calling itself The Front for the Liberation of the Enclave of Cabinda (Flec) claimed responsibility for the assault, which resulted in serious injuries being suffered by a number of players and the death of the bus driver. Cabinda is an oilrich region of northern Angola, which has sought independence for many decades from the remainder of Angola, and Flec, which was thought to be operating a ceasefire from 2006, clearly identified the staging of the Africa Cup of Nations as an opportunity for an escalation in its campaign for independence (BBC, 2010).

Thus a collection examining sport and terrorism brings together arguably two of the most pervasive themes of modern life (Atkinson and Young, 2002). Many countries seemingly operate under at least the fear of attack from rogue elements either within their own state boundaries or from pan-national terrorist movements (Neumann and Smith, 2008). There is, it seems, a culture of marked caution and suspicion existing at a subconscious level within many countries whilst this exists alongside a considerable sense of foreboding around possible future, often random, attacks on major cities, infrastructures or civic spectacles (Taylor and Toohey, 2007). At the same time, sport can offer temporary respite from this culture of fear and yet, conversely, it is precisely because it does so that the targeting of sport constitutes a major success for terrorists (Wedermeyer, 1999). Put simply if terrorists are to achieve their primary aims of creating fear, instability and exercising a challenge to the sitting government then promoting this message within a non-political and ostensibly joyous setting, such as sport, presents their work with added agency (Riordan, 1998).

Whilst by no means representing a substantial body of work there has been an increasing focus on the part of scholars upon the sport-terrorism nexus. That said, this has only emerged markedly over the last decade as prior to this, as Wedermeyer (1999) correctly observed at the time, 'specialist literature on the relationship between sport and terrorism is rare' (p. 218). Atkinson and Young's (2002) somewhat prophetic writings, which included the assertion that 'we cannot ignore how sports events may become targets of terrorism' (p. 54) clearly conditioned the minds of sports scholars and enthusiasts at large that sport remained a very real focus of attack in the terrorists' strategic arsenal (Taylor and Toohey, 2007). Evidence of previous work, notably at the Summer Olympic Games, suggests that so-called mega-events represented the primary focus for certain terrorist cells (Horne and Manzenreiter, 2006). The rationale for this includes an obvious 
assertion that the presence of the international media corps facilitates the broadcasting of any resulting atrocity to all parts of the world. Additionally, there is the less immediately impactful conclusion that investment and focus on actually preventing a terrorist attack from happening in the first place means that a state administration must divert resources away from other aspects of a nation's everyday life, including health, education and infrastructural investment, resulting in growing agitation on the part of that country's people against the sitting government, not to mention presenting opportunities for terrorists to strike elsewhere within that state (Neumann and Smith, 2008). Thus we must focus our attention not alone on the site of the actual or possible attack but also on the full consequences of the apparent targeting of sport by terrorists organizations the world over. Its outcomes are immediate, progressive and resource intensive and involve not only the protection of the apparent sanctity of the event in question but often the very standing of the nation within the world order (Martin, 2011).

Thus, particularly at major international events, the level of attention, detailed planning and expenditure required to adequately secure some of sport's 'showcase' events is beginning to attract the attention of those who question the value of hosting tournaments like the FIFA World Cup or the Summer Olympic Games in the first place. There is no doubt that security has significantly improved for Olympic athletes and officials since the infamous events of Munich in 1972, when a Palestinian terrorist cell entitled 'Black September' stormed the Israeli residential halls in an attack that ultimately claimed the lives of 11 athletes and a policeman. But it failed to prevent a further, albeit minor, attack prior to the Atlanta Summer Games in 1996 whilst the staging of subsequent tournaments in comparatively benign settings, such as Australia and Greece, have meant the prospects of the Games being targeted in any meaningful manner has remained low (Arnaud and Riordan, 1998). This should not imply that the threat of attack is absent in the minds of the Games' organizers and the state authorities. For example, just five days before the Olympic flame was lit in Beijing in 2008, there was an attack by Muslim separatists in the city of Kashgar in China's far western Xinjiang region that left 16 policemen dead and an equal number badly wounded. It appears even the best laid plans are comparatively futile in the face of determined terrorist cells, which show no regard for political cultures, ideologies or world standings.

However, it is entirely appropriate to suggest that such a focus on major sporting events has tended to mask more regular attacks at the local or national level. The ETA bomb blast in Madrid in 2002, prior to the UEFA Champions League semi-final between Real Madrid and Barcelona, was clearly designed to maximize publicity for its campaign of autonomy within Spain and across Europe. The bomb attack was considered a reprisal upon elements of the Spanish establishment, thought to be sympathetic to Real Madrid $\mathrm{FC}$, for the arrest and detention of 11 members of Batasuna (the political wing of ETA) on the day of game. Similarly, the highpoint of the 1997 steeplechase season in the UK, the Aintree Grand National, was abandoned when two separate bomb warnings were received by the event's organizers, from the Irish Republican Army (IRA) ahead of the eagerly anticipated annual horse race. For much of the IRA's modern campaign in Northern Ireland one element of its strategy (to secure Irish independence and sovereignty from Britain) has included attacks in Britain. Another republican terrorist grouping, the Irish National Liberation Army (INLA) had targeted sporting events on previous 
occasions, notably the World Cup Qualifier in 1985 held in Windsor Park, Belfast between Northern Ireland and England. However, this was the first instance when a major sporting spectacle was disrupted in Britain in such a high profile fashion. More recently, the actions of a Tamil Tiger suicide bomber at the start of the Sri Lankan Marathon of 2008 led to the deaths of 12 people and more than 100 injured competitors. Amongst the dead were Sri Lankan Highways minister Jeyaraj Fernandopulle and former Olympic marathon runner KA Karunaratne. Again with the attention of the national and regional media being drawn to the event, organized to mark the beginning of the Sri Lankan New Year, it constituted the ideal setting to launch an attack of this nature.

Whilst events like those listed here will inevitably attract the public gaze it is also important to highlight how the consequence of terrorism, which is not directly targeted at sport, has nevertheless succeeded in affecting and disrupting it. Two comparatively recent examples again serve to illustrate this point; the postponement of the 2001 Ryder Cup tournament and the cancellation of the 2008 Dakar Rally (Martin, 2011). Both were affected by the actions of Al Qaeda, whose attack on New York on 11 September 2001 ultimately claimed the lives of more than 3000 people. Whilst the 2001 Ryder Cup, due to be staged at the Belfry, England was postponed as it was felt it would be inappropriate to stage the event so close to the attacks in America, the Dakar Rally was cancelled following security advice received from the French authorities regarding the potential targeting of the event, staged in north Africa. French intelligence sources pointed to the killing of French tourists in Mauritania - where eight of the rally's proposed 15 stages were to be held - as evidence that Al Qaeda was active in the region and may consider an attack on the Dakar competitors as justifiable on account of the publicity it would bring their activities in the region and across the Muslim world. Indeed, there has been an emerging strand of research around the management of sporting facilities generally in the wake of the $9 / 11$ terrorist attacks and this is likely to escalate in line with the heightened terrorist threats around sport generally (Appelbaum et al., 2005).

In summary, the essays contained within this special issue provide a comprehensive account of the current research and analysis around sport and terrorism. Written by many of the leading authorities on the subject they are intended to provide a space for critical reflection about how sport exercises a much more profound influence upon the lives of modern nations than might ever have been considered heretofore. In August 2012, London, regarded by many as an erstwhile modern European city, will host the Summer Olympic Games for the first time in more than 60 years. Much has changed in the interim period, not least how London (and Britain) is viewed internationally and the extent to which terrorist organizations, from Al Qaeda to dissident Irish republican groupings, such as the Real IRA, see the Games as an opportunity to remind the British administration and the world at large that when it comes to reaffirming their presence and opposition to aspects of British foreign policy there are no options beyond consideration.

\section{Funding}

This research received no specific grant from any funding agency in the public, commercial, or not-for-profit sectors. 


\section{References}

Appelbaum S, Adeland E and Harris J (2005) Management of sports facilities: Stress and terrorism since 9/11. Management Research 28(7): 69-83.

Arnaud P and Riordan J (eds) (1998) Sport and International Politics. London: E \& FN Spon.

Atkinson M and Young K (2002) Terror games: Media treatment of security issues at the 2002 Winter Olympic Games. Olympika: The International Journal of Olympic Studies 9: 53-78.

BBC (2010) Available at: www.bbc.co.uk, 8 January (accessed 25 September 2011).

Berry S (2009) Terrorist attack on Sri Lankan cricketers will not stop the IPL. The Independent, 7 March, p. 34.

Horne J and Manzenreiter W (2006) An introduction to the sociology of sports mega-events. Sociological Review s2: 1-24.

Martin G (2011) Essentials of Terrorism, 2nd edn. Los Angeles, CA: SAGE.

Neumann P and Smith M (2008) The Strategy of Terrorism. London: Routledge.

Riordan J (1998) Introduction. In: Arnaud P and Riordan J (eds) Sport and International Politics. London: E \& FN Spon, 1-2.

Taylor T and Toohey K (2007) Perceptions of terrorism threats at the 2004 Olympics Games: Implications for sport events. Journal of Sport and Tourism 12(2): 99-114.

Wedermeyer B (1999) Sport and terrorism. In: Riordan J and Kruger A (eds) The International Politics of Sport in the $20^{\text {th }}$ Century. New York: Routledge, 217-231.

Wilkinson P (2001) Terrorism versus Democracy. London: Routledge. 